\title{
DUKUNGAN KELUARGA SEBAGAI FAKTOR DOMINAN KEBERHASILAN MENYUSUI EKSKLUSIF
}

\section{Family's Support as the Dominant Factor of Exclusive Breastfeeding}

\author{
Mery Ramadani \\ Bagian Kesehatan Reproduksi Fakultas Kesehatan Masyarakat Universitas Andalas \\ (meryramadani81@yahoo.com)
}

\begin{abstract}
ABSTRAK
Meskipun manfaat pemberian ASI eksklusif sudah diakui secara luas, tetapi angka pencapaian Kota Padang Panjang masih di bawah target yang ditetapkan oleh Kementerian Kesehatan. Tujuan penelitian adalah mengetahui dukungan keluarga dalam pemeberian ASI eksklusif di Kota Padang Panjang. Penelitian dengan desain crosssectional, dilakukan pada bulan Desember 2014-Juli 2015. Populasi sebanyak 412 dengan jumlah sampel 208 ibu yang memiliki bayi berusia $>6-12$ bulan. Pengambilan sampel dengan menggunakan teknik multistage random sampling. Pengolahan data menggunakan uji chi square untuk bivariat dan untuk multivariat dengan analisis Regresi Logistik Ganda. Sebanyak 22,6\% ibu memberikan ASI eksklusif, dan 70,7\% ibu mendapat dukungan keluarga dalam pemberian ASI eksklusif. Ada hubungan antara dukungan keluarga dengan pemberian ASI eksklusif, ibu yang keluarganya mendukung pemberian ASI eksklusif berpeluang memberikan ASI eksklusif 3,5 kali daripada ibu yang keluarganya kurang mendukung pemberian ASI eksklusif setelah dikontrol pengetahuan ibu dan pengalaman menyusui ibu. Kesimpulan penelitian ini adalah ada hubungan dukungan keluarga dengan ASI Eksklusif. Mengingat besarnya peran keluarga dalam keberhasilan pemberian ASI eksklusif, maka keluarga perlu dijadikan sasaran penyuluhan ASI dan didorong untuk lebih aktif mencari informasi serta aktif belajar mengenai ASI, sehingga lebih paham dalam memberikan dukungan kepada ibu untuk menyusui secara eksklusif.
\end{abstract}

Kata kunci : ASI eksklusif, dukungan keluarga, pengetahuan, IMD

ABSTRACT

Despite broad recognition of benefits associated with breastfeeding, rates in the Padang panjang City continue to be below targets established by Ministry of Health. The purpose of this research was to determine the dominant factors associated with exclusive breastfeeding in Padang Panjang City. Cross-sectional design was used in this study that was conducted from December 2014 until July 2015. Population was 412 mothers who have babies aged > 6-12 months. A total of sample was 208 selected using multystage random sampling method. Bivariate analysis was conducted using chi square test and multivariate analysis using multiple logistic regression test. Results of study found only 22,6\% of respondents did exclusive breastfeeding, and 70,7\% mothers gained family's support in exclusive breastfeeding. There was a relationship between family's support and exclusive breastfeeding whereas mothers who had family' support likely do exclusive breastfeeding three times than mothers without family's support after adjusted by mother's knowledge, and experience of exclusive breastfeeding. As the role of family is important in exclusive breastfeeding, therefore family should became the target of education on exclusive breastfeeding and encourage them to be more active in searching information about exclusive breastfeeding, so that they would support mother in exclusive breastfeeding.

Keywords : Exclusive breastfeeding, family's support, knowledge, EIB 


\section{PENDAHULUAN}

Air Susu Ibu (ASI) merupakan makanan utama yang sangat dibutuhkan oleh bayi. Tidak ada makanan lain yang mampu menyaingi kandungan gizi ASI. ASI mengandung protein, lemak, gula, kalsium dengan kadar yang tepat. Dalam ASI juga terdapat zat-zat yang disebut antibodi, yang melindungi bayi dari serangan penyakit selama ibu menyusui bayi dan beberapa waktu sesudahnya. ${ }^{1}$

Menurut UNICEF, ASI ekslusif dapat menekan angka kematian bayi di Indonesia. UNICEF menyatakan bahwa 30.000 kematian bayi di Indonesia dan 10 juta kematian anak balita di dunia setiap tahun bisa dicegah melalui pemberian ASI eksklusif selama enam bulan sejak satu jam pertama setelah kelahirannya tanpa memberikan makanan dan minuman tambahan kepada bayi. ${ }^{2}$

Angka kematian bayi di Indonesia hasil Survei Demografi Kesehatan Indonesia 2012 adalah 32 kematian per 1.000 kelahiran hidup. Target yang hendak dicapai tahun 2015 adalah 23 kematian per 1.000 kelahiran hidup. Menurunkan angka kematian bayi adalah salah satu tujuan Milinium Devolepment Goals (MDGs) yang merupakan prioritas pembangunan kesehatan Indonesia. Salah satu upaya yang dapat dilakukan untuk menurunkan angka kematian bayi adalah dengan peningkatan pemberian ASI eksklusif. ${ }^{2}$

Pemerintah Indonesia telah membuat rencana aksi akselerasi pemberian ASI eksklusif, yang merupakan upaya terobosan dalam rangka percepatan peningkatan pencapaian target untuk melindungi, meningkatkan dan mendukung program ASI melalui regulasi, advokasi, sosialisasi dan peningkatan kapasitas tenaga kesehatan. Namun, pencapaian ASI ekslusif di Indonesia masih juga rendah, di bawah target $80 \%{ }^{3}$ Berdasarkan Survei Demografi Kesehatan Indonesia tahun 2012, persentase bayi 0-6 bulan yang mendapatkan ASI ekslusif sebesar $41 \%$ dan meningkat $(54,3 \%)$ tahun 2013. Persentase pemberian ASI ekslusif tertinggi di Nusa Tenggara Barat (79,74\%), dan terendah di Provinsi Maluku (25,21\%). Sumatera Barat berada pada posisi ke-6 dengan 68,91\%.2,4

Data Dinas Kesehatan Sumatera Barat menunjukkan kenaikan pencapaian ASI ekslusif Sumatera Barat tahun 2014 dari tahun sebelumnya, yaitu dari $67,4 \%$ menjadi $72,5 \%$, tetapi angka ini masih belum mencapai target provinsi yaitu
80\%. Posisi Kota Padang Panjang berada diurutan ke tujuh dari sembilan belas kabupaten/kota di Sumetera Barat dengan capaian $75 \%$. Dari data Dinas Kesehatan Padang Panjang tiga tahun terakhir tidak terjadi kenaikan pencapaian cakupan ASI Ekslusif. Pada tahun 2012 capaian ASI eksklusif 76,6\%, tahun 2013 menurun menjadi 75,7\%, dan pada tahun 2014 tetap sebesar $75 \%$ dan belum mencapai target $80 \%{ }^{5}$

Secara demografis, Kota Padang Panjang merupakan daerah kecil yang luasnya hanya 0,05\% dari luas Provinsi Sumatera Barat dengan penduduk yang tidak terlalu menyebar. Kondisi ini idealnya menjadi faktor pendukung yang memudahkan tenaga kesehatan dalam melakukan intervensi kesehatan, salah satunya mengenai ASI ekslusif. $^{5}$

Debra Hector dan kawan-kawan mengelompokkan faktor yang memengaruhi praktik menyusui dalam tiga tingkatan, yaitu faktor tingkat individu, faktor tingkat kelompok dan faktor tingkat masyarakat. Faktor tingkat individu meliputi atribut bayi, atribut ibu, dan atribut keduanya ibu dan bayi. Faktor tingkat masyarakat meliputi atribut lingkungan rumah sakit dan pelayanan kesehatan, lingkungan rumah/keluarga, lingkungan kerja, lingkungan masyarakat dan lingkungan kebijakan publik. Sedangkan faktor tingkat masyarakat meliputi atribut masyarakat, budaya dan ekonomi. Salah satu yang termasuk faktor individu, dan memainkan peran besar dalam keberhasilan ASI eksklusif adalah dukungan dari keluarga sebagai orang terdekat ibu. ${ }^{6}$ Tujuan penelitian ini melihat dukungan keluarga dalam praktik pemberian ASI eksklusif setelah dikontrol oleh faktor-faktor lain yang diduga berkontribusi. Faktor tersebut meliputi niat, pengetahuan, pengalaman menyusui eksklusif, IMD, dukungan tenaga kesehatan.

\section{BAHAN DAN METODE}

Penelitian ini menggunakan desain potong lintang untuk melihat faktor yang paling dominan berhubungan dengan pemberian ASI eksklusif. Penelitian dilakukan di Kota Padang Panjang bulan April sampai dengan Juni 2015. Populasi penelitian adalah semua ibu yang mempunyai bayi berusia $>6-12$ bulan dengan jumlah 412 orang. Sampel adalah sebagian anggota populasi yang memenuhi 
kriteria inklusi dan eksklusi. Besar sampel dihitung menggunakan rumus jumlah sampel untuk uji hipotesis 2 proporsi dari Lameshow.

Hasil perhitungan sampel minimal yang dibutuhkan adalah 52 orang untuk masing-masing kelompok, maka jumlah total sampel minimal yang dibutuhkan untuk penelitian ini adalah 104 orang. Karena menggunakan multistange random sampling dengan posyandu sebagai unit terkecil, maka diperlukan adanya perhitungan desain effect. Diperkirakan besarnya desain effect dari sistem pengambilan sampel adalah 2. Jadi total sampel yang diperlukan adalah jumlah sampel dikali desain effect sebanyak 208 responden. Sampel penelitian harus memenuhi kriteria inklusi dan eksklusi. Kriteria inklusi antara lain bersedia menjadi responden dan mampu berkomunikasi dengan baik. Kriteria eksklusi jika bayi pada usia 0-6 bulan menderita penyakit parah/kelainan bawaan. Data yang dikumpulkan meliputi praktik pemberian ASI, dukungan keluarga, niat ibu, pengetahuan ibu, pengalaman menyusui, proses persalinan, Inisiasi Menyusu Dini (IMD), dan dukungan tenaga kesehatan, diperoleh melalui wawancara langsung menggunakan kuesioner terstruktur yang telah diujicobakan sebelumnya. Variabel dukungan keluarga, niat ibu, dan dukungan tenaga kesehatan dikategorikan berdasarkan nilai tengah. Kategorisasi pengetahuan ibu ditentukan berdasarkan jawaban benar dengan batas $60 \%$ dari total skor. Analisis univariat dilakukan untuk mendapatkan informasi tentang frekuensi dan persentase dari variabel yang diamati. Uji kai kuadrat digunakan untuk menganalisis hubungan variabel independen dengan dependen yang berskala ordinal. Perbedaan bermakna dinyatakan jika nilai $\mathrm{p}<0,05$. Perhitungan odds ratio (OR) dilakukan dengan mengontrol variabel kovariat yang bermakna secara statistik (nilai $\mathrm{p}<0,05$ ) dan diduga mengganggu hubungan antara dukungan keluarga dengan pemberian ASI eksklusif.

\section{HASIL}

Hasil penelitian mendapatkan rata-rata umur ibu adalah 30 tahun dengan umur terendah 18 tahun dan tertinggi 42 tahun. Latar belakang pendidikan terbanyak tamat SLTA $(46,2 \%)$ dan sebagian besar $(70,2 \%)$ adalah ibu rumah tangga. Hanya sebagian kecil ibu $(22,6 \%)$ yang memberi-
Tabel 1. Karakteristik Responden dan Distribusi Frekuensi Variabel Penelitian

\begin{tabular}{|c|c|c|}
\hline Karakteristik & $\mathbf{n}$ & $\%$ \\
\hline \multicolumn{3}{|l|}{ Tingkat Pendidikan } \\
\hline SD & 17 & 8,2 \\
\hline SMP & 22 & 10,6 \\
\hline SMA & 96 & 46,2 \\
\hline Akademi/PT & 73 & 35,1 \\
\hline \multicolumn{3}{|l|}{ Pekerjaan } \\
\hline Ibu Rumah Tangga & 146 & 70,2 \\
\hline Pedagang & 9 & 4,3 \\
\hline Pegawai swasta & 8 & 3,8 \\
\hline PNS & 36 & 17,3 \\
\hline Lainnya & 9 & 4,3 \\
\hline \multicolumn{3}{|l|}{ ASI Ekslusif } \\
\hline $\mathrm{Ya}$ & 47 & 22,6 \\
\hline Tidak & 161 & 77,4 \\
\hline \multicolumn{3}{|l|}{ Dukungan Keluarga } \\
\hline Mendukung & 147 & 70,7 \\
\hline Kurang mendukung & 61 & 29,3 \\
\hline \multicolumn{3}{|l|}{ Niat } \\
\hline Kuat & 134 & 64,4 \\
\hline Kurang & 74 & 35,6 \\
\hline \multicolumn{3}{|l|}{ Pengetahuan } \\
\hline Tinggi & 109 & 52,4 \\
\hline Rendah & 99 & 47,6 \\
\hline \multicolumn{3}{|c|}{ Pengalaman Menyusui Ekslusif } \\
\hline Ada & 70 & 33,7 \\
\hline Tidak ada & 138 & 66,3 \\
\hline \multicolumn{3}{|l|}{ Proses Persalinan } \\
\hline Pervaginam & 175 & 84,1 \\
\hline Caesar & 33 & 15,9 \\
\hline \multicolumn{3}{|l|}{ IMD } \\
\hline $\mathrm{Ya}$ & 89 & 42,8 \\
\hline Tidak & 119 & 57,2 \\
\hline \multicolumn{3}{|c|}{ Dukungan Tenaga Kesehatan } \\
\hline Mendukung & 134 & 64,4 \\
\hline Kurang mendukung & 74 & 35,6 \\
\hline
\end{tabular}

kan ASI secara eksklusif, tetapi lebih dari separuh ibu (70,7\%) menilai keluarga cukup memberikan dukungan dalam pemberian ASI eksklusif. Sebanyak $88,9 \%$ keluarga menyarankan ibu untuk memberikan ASI eksklusif, tetapi hanya 43,3\% keluarga yang melarang ibu memberikan makanan/ minuman lainnya kepada bayi selama usia 6 bulan pertama. Umumnya ibu $(84,1 \%)$ menjalani persalinan pervaginam, tetapi hanya $42,8 \%$ saja yang melakukan IMD. Waktu rata-rata yang dibutuhkan dari pertama bayi diletakkan di dada ibu sampai bayi berhasil menyusu adalah lima menit (50,8\%) (Tabel 1). Alasan tidak melakukan IMD antara lain 
tidak difasilitasi oleh tenaga kesehatan, bayi lahir prematur, bayi langsung dimasukkan ke inkubator, dan proses melahirkan secara caesar.

Berdasarkan scoring, diketahui 33,7\% mempunyai pengalaman menyusui eksklusif. $64,4 \%$ ibu memiliki niat kuat untuk menyusui, $57,7 \%$ diantaranya rajin untuk melakukan perawatan payudara untuk persiapan menyusui. Sebanyak 52,4\% ibu memiliki pengetahuan tinggi. Sebagian besar ibu $(83,2 \%)$ mengetahui definisi ASI ekslusif, tetapi hanya $19,7 \%$ yang mengetahui tanda bayi kekurangan ASI. Dukungan dari tenaga kesehatan didapatkan oleh lebih dari separuh ibu $(64,4 \%)$. Sebanyak 73,6\% ibu mendapat informasi mengenai keuntungan dan keunggulan ASI, tetapi
ASI eksklusif (Tabel 2). Setelah dilakukan analisis multivariat menggunakan uji regresi logistik ganda, diketahui pengetahuan dan pengalaman menyusui eksklusif merupakan confounder hubungan dukungan keluarga dengan pemberian ASI secara eksklusif (Tabel 3).

\section{PEMBAHASAN}

Penelitian ini melibatkan 208 responden, yaitu ibu-ibu yang memiliki bayi berusia 7 sampai 12 bulan. Hasil penelitian menunjukkan hanya sebagian kecil $(22,6 \%)$ ibu yang memberikan ASI secara eksklusif, sedangkan $77,4 \%$ ibu lainnya sudah memberikan susu formula dan/atau makanan pendamping ASI sebelum bayi mereka berusia 6

Tabel 2. Pemberian ASI Ekslusif Berdasarkan Variabel Penelitian

\begin{tabular}{|c|c|c|c|c|c|c|}
\hline \multirow{3}{*}{ Variabel } & \multicolumn{5}{|c|}{ ASI Ekslusif } & \multirow{3}{*}{$\mathbf{p}$} \\
\hline & \multicolumn{2}{|c|}{ Ya } & \multicolumn{2}{|c|}{ Tidak } & \multirow{2}{*}{ Total } & \\
\hline & $\mathbf{n}$ & $\%$ & $\mathbf{n}$ & $\%$ & & \\
\hline \multicolumn{7}{|l|}{ Dukungan Keluarga } \\
\hline Mendukung & 42 & 28,6 & 105 & 71,4 & 147 & 0,003 \\
\hline Kurang mendukung & 5 & 8,2 & 56 & 91,8 & 61 & \\
\hline \multicolumn{7}{|l|}{ Niat } \\
\hline Kuat & 37 & 27,6 & 97 & 72,4 & 134 & 0,031 \\
\hline Kurang & 10 & 13,5 & 64 & 86,5 & 74 & \\
\hline \multicolumn{7}{|l|}{ Pengetahuan } \\
\hline Tinggi & 33 & 30,3 & 76 & 69,7 & 109 & 0,009 \\
\hline Rendah & 14 & 14,1 & 85 & 85,9 & 99 & \\
\hline \multicolumn{7}{|c|}{ Pengalaman Menyusui Ekslusif } \\
\hline Ada & 26 & 37,1 & 44 & 62,9 & 70 & 0,001 \\
\hline Tidak ada & 21 & 15,2 & 117 & 84,8 & 138 & \\
\hline \multicolumn{7}{|l|}{ Proses Persalinan } \\
\hline Pervaginam & 42 & 24,0 & 133 & 76,0 & 175 & 0,375 \\
\hline Caesar & 5 & 15,2 & 28 & 84,8 & 33 & \\
\hline \multicolumn{7}{|l|}{ IMD } \\
\hline Ya & 30 & 33,7 & 59 & 66,3 & 89 & 0,002 \\
\hline Tidak & 17 & 14,3 & 102 & 85,7 & 119 & \\
\hline \multicolumn{7}{|c|}{ Dukungan Tenaga Kesehatan } \\
\hline Mendukung & 36 & 26,9 & 98 & 73,1 & 134 & 0,071 \\
\hline Kurang Mendukung & 11 & 14,9 & 63 & 85,1 & 74 & \\
\hline
\end{tabular}

masih ada $45,7 \%$ tenaga kesehatan yang memberi sampel susu formula kepada ibu bersalin untuk dibawa pulang. Terdapat hubungan yang signifikan antara dukungan keluarga $(\mathrm{p}=0,003)$ dengan pemberian ASI eksklusif (Tabel 2). Untuk variabel kovariat, didapatkan hubungan niat $(\mathrm{p}=0,031)$, pengetahuan $(p=0,009)$, pengalaman menyusui eksklusif $(p=0,001)$, IMD $(p=0,002)$ dengan pemberian bulan. Rendahnya cakupan pemberian ASI eksklusif ini sejalan dengan hasil SDKI 2012 sebesar $41 \%$, jauh dari target nasional $80 \%$. Hasil serupa didapatkan pada penelitian Destriatania di daerah urban Jakarta yang menyebutkan 70,9\% bayi tidak diberi ASI eksklusif. ${ }^{7}$

Cakupan yang masih rendah bisa disebabkan persepsi keliru ibu mengenai ASI eksklusif. 
Tabel 3. Penentuan Confounder pada Hubungan antara Dukungan Keluarga dengan Pemberian ASI Eksklusif

\begin{tabular}{lcccl}
\hline \multicolumn{1}{c}{ Variabe } & OR Crude & OR Adjusted & Perubahan & \multicolumn{1}{c}{ Keterangan } \\
\hline Dukungan nakes & 3,168 & 3,192 & $0,7 \%$ & Bukan confounder \\
Niat & 3,168 & 3,438 & $8,5 \%$ & Bukan confounder \\
Pengetahuan & 3,168 & 3,901 & $23 \%$ & Confounder \\
Pengalaman menyusui & 3,168 & 3,962 & $25 \%$ & Confounder \\
IMD & 3,168 & 3,479 & $9,8 \%$ & Bukan confounder \\
\hline
\end{tabular}

Tabel 4. Model Akhir Hubungan Dukungan Keluarga dengan Pemberian ASI Eksklusif

\begin{tabular}{lccccc}
\hline \multicolumn{1}{c}{ Variabel } & B & SE & Nilai p & OR & 95\%CI \\
\hline Dukungan keluarga & 1,274 & 0,516 & 0,016 & 3,479 & $1,266-9,558$ \\
Pengetahuan & 0,973 & 0,376 & 0,010 & 2,645 & $1,265-5,532$ \\
Pengalaman menyusui eksklusif & 1,140 & 0,361 & 0,002 & 3,126 & $1,541-6,341$ \\
\hline \multicolumn{1}{c}{ Konstanta } & $\mathbf{0 , 1 0 0}$ & $\mathbf{0 , 3 0 8}$ & $\mathbf{0 , 7 4 5}$ & $\mathbf{0 , 9 0 5}$ & \\
\hline
\end{tabular}

Pada kelompok ibu tidak ASI eksklusif mayoritas $(73,3 \%)$ adalah ibu rumah tangga, $49,7 \%$ menamatkan SLTA, dan 47,2\% memiliki pengetahuan tinggi, tetapi masih ada anggapan memberi air putih kepada bayi masih tergolong ASI eksklusif. Sebanyak $22,4 \%$ ibu sudah memberikan makanan selain ASI saat bayi berumur satu bulan. Makanan dan minuman yang diberikan antara lain air putih, madu, susu formula, bubur dan pisang. Alasan ibu memberikan makanan dan minuman selain ASI karena setelah melahirkan ASI belum keluar, mengganggap ASI mereka sedikit, bayi tidak kenyang kalau hanya diberi ASI saja, ibu mencoba-coba memberi bayi makanan selain ASI, bayi cegukan, bayi demam, ibu demam, ibu yang bepergian, ibu bekerja dan mengikuti pola pemberian ASI anak sebelumnya.

Hasil studi ini juga membuktikan hubungan antara dukungan keluarga dengan pemberian ASI secara eksklusif setelah dikontrol pengetahuan dan pengalaman menyusui. Praktik menyusui eksklusif berpeluang 3,5 kali lebih berhasil dengan dukungan keluarga dibandingkan tanpa mendapat dukungan keluarga. Sejalan dengan penelitian sebelumnya oleh Fox, dkk., mengenai pentingnya dukungan yang tepat khususnya di minggu pertama postnatal. Dukungan sosial dan keluarga yang efektif, dikombinasikan dengan bimbingan dari praktisi terampil dapat membantu perempuan untuk mengatasi kesulitan dan menemukan kepercayaan diri mereka untuk menyusui. ${ }^{16} \mathrm{Ke}$ luarga memberikan kontribusi yang besar terhadap keinginan ibu untuk menyusui bayi selain memberikan pengaruh yang kuat untuk pengambilan keputusan untuk tetap menyusui.

Pengetahuan merupakan confounder hubungan dukungan keluarga dengan pemberian ASI secara eksklusif . Artinya, pengetahuan ibu memengaruhi hubungan dukungan keluarga dengan pemberian ASI secara eksklusif Pemberian ASI secara eksklusif cenderung lebih tinggi pada ibu yang memiliki pengetahuan dan pengalaman menyusui eksklusif. Pengetahuan yang memadai akan membantu ibu dalam menghadapi mitos dan pemahaman yang salah mengenai ASI. Hasil penelitian Djami, dkk., menyebutkan frekuensi paparan pengetahuan berhubungan dengan keberhasilan praktik menyusui ekslusif ibu. Salah satu sumber paparan pengetahuan tersebut didapat melalui konseling. Semakin sering terpapar informasi yang benar tentang proses laktasi, akan dapat meningkatkan keterampilan ibu dalam pemberian ASI eksklusif. Pengetahuan ibu yang baik tentang ASI eksklusif akan meningkatkan pemberian ASI eksklusif sebanyak empat kali. Hasil penelitian ini mendukung teori perilaku kesehatan menurut Green yang menyatakan bahwa pengetahuan merupakan salah satu pendorong seseorang untuk merubah perilaku atau mengadopsi perilaku baru. ${ }^{8}$

Pengalaman menyusui eksklusif merupakan confounder hubungan dukungan keluarga dengan pemberian ASI secara eksklusif. Hal ini berarti, pengalaman ibu memengaruhi hubungan dukungan keluarga dengan pemberian ASI secara 
eksklusif. Pengalaman yang didapat ibu sebelumnya, membentuk sikap positif ibu untuk mempraktikkan pemberian ASI yang lebih baik pada anak berikutnya. ${ }^{9}$ Pengalaman menyusui yang dimiliki seorang ibu sebelumnya memainkan peran yang lebih signifikan terhadap perilaku menyusui berikutnya. Keberhasilan menyusui eksklusif saat ini menentukan keberhasilan menyusui eksklusif anak selanjutnya. Umumnya, ibu dengan pengalaman menyusui eksklusif merupakan ibu multipara yang memiliki pengetahuan lebih baik, lebih percaya diri dan lebih terampil dalam praktik menyusui. Namun, ibu primipara dapat memanfaatkan semua bantuan baik dari tenaga kesehatan maupun keluarga guna suksesnya praktek menyusui. Keberhasilan praktik menyusui eksklusif ibu primipara sangat penting, karena berdampak pada keberhasilan prkatik menyusui anak berikutnya. ${ }^{10}$

Niat berhubungan erat dengan keberhasilan praktik menyusui eksklusif. Noughabi, dkk., menyebutkan sikap positif saja tidaklah cukup, niat ibu yang kuat juga dibutuhkan untuk suksesnya praktik menyusui eksklusif. ${ }^{11}$ Niat merupakan indikator seberapa besar seseorang bersedia untuk mencoba, atau berapa banyak upaya seseorang bersedia untuk melakukan suatu tindakan. Semakin kuat niat ibu untuk menyusui secara eksklusif semakin besar kemungkinan dia harus benar-benar menyusui eksklusif. ${ }^{12}$ Niat ibu dapat diukur dari upaya yang dilakukan ibu sepanjang kehamilan dan periode menyusui, seperti rutin melakukan perawatan payudara (memijat dan membersihkan puting) dan mencari informasi terkait praktik menyusui. Penelitian ini mendapatkan bahwa niat bukan merupakan confounder hubungan dukungan keluarga dengan pemberian ASI secara eksklusif. Ini artinya, niat ibu tidak memengaruhi penilaian ibu terhadap dukungan keluarga dan tidak memengaruhi pemberian ASI secara eksklusif. Dukungan keluarga dan praktik pemberian ASI eksklusif tidak hanya dipengaruhi niat ibu. Pada perjalanannya, antusiasme ibu untuk memberikan ASI eksklusif sebagian terkendala oleh dukungan petugas kesehatan yang kurang saat persalinan.

Lebih dari separuh ibu tidak mendapat pelayanan IMD oleh tenaga kesehatan. Padahal, bayi yang diberi kesempatan IMD berpeluang lebih besar untuk menyusu ASI secara eksklusif dibanding bayi yang tidak diberikan kesempat- an IMD. Salah satu faktor yang mempengaruhi keberhasilan ASI eksklusif adalah kemampuan untuk melakukan penyusuan segera (immediate breastfeeding). Salah satu kunci utama keberhasilan IMD terletak pada penolong persalinan karena dalam menit-menit pertama setelah bayi lahir peran penolong persalinan sangat dominan. Apabila ibu difasilitasi oleh penolong persalinan untuk IMD diharapkan interaksi ibu dan bayi ini akan segera terjadi. Dengan IMD, ibu semakin percaya diri untuk tetap memberikan ASI. Ibu tidak merasa perlu untuk memberikan makanan/minuman apapun kepada bayi karena bayi bisa nyaman menempel pada payudara ibu atau tenang dalam pelukan ibu segera setelah lahir. ${ }^{13,14}$ IMD memegang peran penting dalam pemberian ASI eksklusif. IMD yang berhasil akan merangsang produksi ASI ibu dan jumlah ASI menjadi cukup. Jika telah melakukan IMD, kecenderungan memberikan makanan selain ASI akan berkurang. ${ }^{15}$ Sangat disayangkan jika bayi dari lahir telah diberi makanan selain ASI padahal kesempatan yang dimiliki bayi untuk ASI eksklusif sama. Oleh karena itu, dibutuhkan kerjasama antara ibu dan tenaga kesehatan. Merupakan hak ibu meminta kepada tenaga kesehatan agar melakukan IMD setelah melahirkan dan tenaga kesehatan berkewajiban menjalankan tugasnya sesuai dengan prosedur.

Proses persalinan bukan merupakan confounder hubungan dukungan keluarga dengan pemberian ASI secara eksklusif. Dapat dikatakan bahwa jenis persalinan yang dilalui ibu bukan merupakan faktor penghambat ibu untuk menyusui bayi. Demikian juga dengan tenaga kesehatan, bukan merupakan confounder hubungan dukungan keluarga dengan pemberian ASI eksklusif. Namun, hasil penelitian menunjukkan kecenderungan keberhasilan menyusui eksklusif lebih tinggi pada ibu yang mendapat dukungan petugas kesehatan. Petugas kesehatan mempunyai peranan yang sangat istimewa dalam menunjang pemberian ASI dan mencegah masalah-masalah yang umum terjadi. Sayangnya, tidak semua ibu menilai maksimal dukungan yang diberikan petugas kesehatan. Pada masa kehamilan, hanya 46,7\% ibu yang mendapatkan informasi cara menyusui bagi ibu bekerja. Pada waktu persalinan hanya 50,7\% yang melakukan inisiasi menyusu dini. Ibu yang menilai dukungan tenaga kesehatan kurang seba- 
gian besar adalah multipara. Ada anggapan bahwa ibu sudah cukup mendapatkan informasi dan pengalaman pada anak sebelumnya, sehingga petugas kesehatan tidak memberikan informasi jika ibu tidak bertanya terlebih dahulu. Hal lain yang menjadi keprihatinan adalah masih adanya $(45,7 \%)$ tenaga kesehatan yang memberi susu formula kepada ibu bersalin untuk dibawa pulang.

\section{KESIMPULAN DAN SARAN}

Hasil penelitian mendapatkan hanya sebagian kecil ibu yang menyusui bayi secara eksklusif. Sebagian besar ibu mendapat cukup dukungan dari keluarga dan tenaga kesehatan dalam praktik ASI eksklusif. Umumnya ibu menjalani persalinan pervaginam, tetapi kurang dari separuh yang melakukan IMD. Lebih dari separuh ibu memiliki pengetahuan tinggi dan niat kuat untuk menyusui. Diketahui pengetahuan dan pengalaman menyusui eksklusif merupakan confounder hubungan dukungan keluarga dengan pemberian ASI secara eksklusif. Ada hubungan antara dukungan keluarga dengan pemberian ASI eksklusif, ibu yang keluarganya mendukung pemberian ASI eksklusif berpeluang memberikan ASI eksklusif 3,5 kali daripada ibu yang keluarganya kurang mendukung pemberian ASI eksklusif setelah dikontrol pengetahuan ibu dan pengalaman menyusui ibu.

Mengingat pentingnya dukungan keluarga terhadap keberhasilan menyusui eksklusif, maka perlu diupayakan dukungan maksimal anggota keluarga kepada ibu terutama selama fase menyusui eksklusif berlangsung. Suami dapat berperan aktif dalam keberhasilan pemberian ASI dengan jalan memberikan dukungan secara emosional dan bantuan-bantuan praktis lainnya. Anggota keluarga seperti orangtua dan kerabat, diharapkan membantu menciptakan atmosfir menyusui yang positif bagi ibu. Memberikan dukungan dan semangat serta membantu ibu mencari solusi seputar masalah menyusui.

\section{DAFTAR PUSTAKA}

1. Eidelman, A. I., Schanler, R. J., Johnston, M., et al. American Academy of Pediatrics Section on Breastfeeding. Breastfeeding and the Use of Human Milk. Pediatrics. 2012;129, e827496-e827841.

2. Statistics Indonesia (Badan Pusat Statistik-
BPS), National Population and Family Planning Board (BKKBN), and Kementerian Kesehatan (Kemenkes-MOH), and ICF International. Indonesia Demographic and Health Survey 2012. Jakarta: BPS, BKKBN, Kemenkes, and ICF International; 2013.

3. Ditjen Bina Gizi dan KIA. Rencana Aksi Akselerasi Pemberian ASI Eksklusif 2012-2014. Jakarta: Kementerian Kesehatan RI; 2012.

4. Kemenkes RI. Profil Kesehatan Indonesia Tahun 2013. Jakarta: Kementerian Kesehatan RI; 2014.

5. Dinkes Kota Padang Panjang. Profil Kesehatan Kota Padang Panjang. Padang Panjang: Dinas Kesehatan Kota Padang Panjang; 20122014.

6. Hektor D, dkk. Factors Affecting Breasfeeding Practice Applying a Conceptual Framework. New South Wales Public Health Bulletin. 2005.

7. Destriatania S, Februhartanty J, Fatmah. Sikap Ayah dan Jumlah Anak serta Praktik Air Susu Ibu Eksklusif. Kesmas Jurnal Kesehatan Masyarakat Nasional. 2013; 8(5): 229-234.

8. Djami MEU, Noormartany, Hilmanto D. Frekuensi Pemeriksaan Kehamilan, Konseling Laktasi, dan Pemberian Air Susu Ibu Eksklusif. Kesmas Jurnal Kesehatan Masyarakat Nasional. 2013; 7(12): 557-561.

9. M. Thaha I L, Razak R, Ansariadi. Detrminan Pemberian ASI Eksklusif oleh Ibu Multipara di Kabupaten Jeneponto. Jurnal MKMI. 2015; 11(1): 247-252.

10. Phillips, dkk. Previous Breastfeeding Practices and Duration of Exclusive Breastfeeding in the United States. Maternal Child Health Journal. 2011; 15(8).

11. Noughabi ZS, dkk. Prevalence and Factors Associated with Exclusive Breasfeeding at 6 Month of Life in Tehran. Teharan Iran. Eastern Mediterranean Health Journal. 2014; 20(1).

12. Shahla M, dkk. Factors that Positively Influence Breastfeeding Duration to 6 Months. Epublications@SCU.2010.

13. Chien LY, Tai CJ. Effect of Delivery Method and Timing of Breastfeeding Initiation on Breastfeeding Outcomes in Taiwan. Birth. 2007; 34(2): 123-30.

14. MacArthur C, Jolly K, Ingram L, Freemantle 
N, Dennis C-L, Hamburger R, et al. Antenatal Peer Support Workers and Initiation of Breastfeeding: Cluster Randomised Controlled Trial. British Medical Journal. 2009; 338

15. Swanson V, Power KG. Initiation and Continuation of Breastfeeding: Theory of Planned Behaviour. Journal of Advanced Nursing.
2005; 50(3):272-82.

16. Fox R, McMullen S, Newburn M. UK Women's Experiences of Breastfeeding and Additional Breastfeeding Support: a Qualitative Study of Baby Café Services. BMC Pregnancy and Childbirth. 2015;15:147. 